\title{
THE INCREASING FEMALE PARTICIPATION IN AUTHORSHIP OF ARTICLES PUBLISHED IN NEUROLOGY IN BRAZIL
}

\author{
Osvaldo M. Takayanagui', José Antonio Livramento
}

\begin{abstract}
During the past four decades the participation of women in medicine has increased dramatically. This study is focused on the women's participation in authorship of articles published in the Arquivos de Neuro-Psiquiatria, the official Journal of the Brazilian Academy of Neurology. The articles were analyzed according to the number of articles and sex of both first and the senior (last) authors. The data were collected from 1945 to 2005. A total of 950 articles were published in this period. The proportion of women serving as first authors increased from $2.8 \%$ to $36.6 \%$ and the proportion serving as senior authors increased from $2.8 \%$ to $23.8 \%(1945-2005)$.
\end{abstract}

KEY WORDS: women in medicine, authorship, neurology, Arquivos de Neuro-Psiquiatria.

\begin{abstract}
A crescente participação da mulher na autoria de trabalhos publicados em neurologia no Brasil
Resumo - Nas últimas quatro décadas houve um aumento crescente na participação de mulheres na medicina. Este artigo apresenta a participação de mulheres como autoras de artigos publicados em Arquivos de NeuroPsiquiatria, jornal oficial da Academia Brasileira de Neurologia. Foi analisada esta participação em quinquênios, a partir de 1945 até 2005. Foram publicados neste período 950 artigos. A participação de mulheres como primeiro autor apresentou aumento de 2,8\% (1945) para 36,6\% (2005) e como último autor (chefe de grupo) passou de 2,8\% (1945) para 23,8\% (2005).
\end{abstract}

PALAVRAS-CHAVE: mulheres médicas, autoria trabalhos, neurologia, Arquivos de Neuro-Psiquiatria.

The medical profession and the scientific production have traditionally been dominated by men but this imbalance is likely to change. In fact, during the past four decades the participation of women in medicine has increased dramatically. In the USA, for example, the proportion of women as authors of articles from six prominent medical journals - N Engl J Med, JAMA, Ann Intern Med, Ann Surg, Obst Gynecol, and J Pediatr - has significatively increased'. In this study we focused on the women's participation in authorship of articles published in the Arquivos de Neuro-Psiquiatria, the official journal of the Brazilian Academy of Neurology.

\section{METHOD}

The articles from the Arquivos de Neuro-Psiquiatria were categorized according to the number of articles and the sex of both first and the senior (last listed) authors. The data were col- lected for the years 1945, 1950, 1955, 1960, 1965, 1970, 1975, 1980, 1985, 1990, 1995, 2000, and 2005.

\section{RESULTS}

A total of 950 articles were published in the journal during the years studied. Overall, $19.5 \%(186 / 950)$ of the first authors and $18.4 \%(175 / 950)$ of the senior authors were women. The proportion of women serving as first authors increased from $2.8 \%(1 / 35)$ to $36.6 \%(77 / 210)$, and the proportion of women serving as senior authors increased from $2.8 \%(1 / 35)$ to $23.8 \%$ (50/210) (Table).

\section{DISCUSSION}

This study demonstrates a substantial increase in women's representation as the principal or senior authors of scientific articles published in the Arquivos de Neuro-Psiquiatria, the main Brazilian journal in the neurology field. Dur-

\footnotetext{
'MD, PhH, Full Professor, Department of Neuroscience and Behaviour, School of Medicine at Ribeirão Preto, University of São Paulo, Ribeirão Preto SP, Brazil; ${ }^{2}$ MD, PhD, Departament of Neurology, School of Medicine, University of São Paulo, São Paulo SP, Brazil.

Received 8 June 2009. Accepted 28 July 2009.

Dr. Osvaldo M. Takayanagui - Department of Neuroscience and Behavior - Av. Bandeirantes 3900 - 14049-900 Ribeirão Preto SP - Brasil. E-mail: omtakay@fmrp.usp.br
} 
Table. Representation of female investigators among first and senior authors of published articles in the Arquivos de Neuropsiquiatria.

\begin{tabular}{cccc}
\hline Year & $\begin{array}{c}\text { Total number } \\
\text { of articles }\end{array}$ & $\begin{array}{c}\text { First author } \\
\text { Number }(\%)\end{array}$ & $\begin{array}{c}\text { Senior author } \\
\text { Number (\%) }\end{array}$ \\
\hline 1945 & 35 & $1(2.8 \%)$ & $1(2.8 \%)$ \\
1950 & 28 & $1(3.5 \%)$ & $1(3.5 \%)$ \\
1955 & 23 & - & $3(13.0 \%)$ \\
1960 & 24 & $1(4.1 \%)$ & - \\
1965 & 28 & - & - \\
1970 & 45 & $2(4.4 \%)$ & $5(11.1 \%)$ \\
1975 & 44 & $7(15.9 \%)$ & $8(18.1 \%)$ \\
1980 & 55 & - & $10(18.1 \%)$ \\
1985 & 63 & $5(7.9 \%)$ & $2(3.1 \%)$ \\
1990 & 82 & $11(13.4 \%)$ & $12(14.6 \%)$ \\
1995 & 134 & $28(20.9 \%)$ & $30(22.3 \%)$ \\
2000 & 179 & $53(29.6 \%)$ & $53(29.6 \%)$ \\
2005 & 210 & $77(36.6 \%)$ & $50(23.8 \%)$ \\
Total & 950 & $186(19.5 \%)$ & $175(18.4 \%)$ \\
\hline
\end{tabular}

ing the period from 1945 to 2005 , the proportion of women serving as first authors increased from $2.8 \%$ to $36.6 \%$, and as senior authors from $2.8 \%$ to $23.8 \%$, respectively.

These data are in accordance with the increasing participation of women in the Brazilian medical practice during the last decades, and reflect the process of equity between sexes that allows a same professional opportunity. This may be confirmed by the analysis of some Brazilian regulatory organizations and professional societies.

The female proportion as active members of the Brazilian Academy of Neurology is 472/1,352 (25.8\%).

According to the Brazilian Federal Council of Medicine, there are 132,767 (38.8\%) women among 341,765 active physicians in Brazil ${ }^{2}$. The historical strong predominance of men in Brazil is clearly changing due to the increasing proportion of women as new professionals. In fact, in the last three consecutive years, there have been more women than men as new members of the Regional Council of Medicine of the São Paulo State, the most populous State in Brazil. The serial historical data point out the significant growing of female presence: in 1980, the proportion of women was $33.5 \%$ of 2,267 new members; in $1990,43.3 \%$ of 2,293 ; in $2000,44.6 \%$ of 2,562 . The invertion of this scenario occurred in 2006, confirmed in 2007 and 2008. In 2006, 1,568 (51.7\%) of 3,030 new members were women; in $2007,1,319(53.8 \%)$ of 2,449 , and in $2008,1,627(52.9 \%)$ of $3,072^{3}$. Nowadays, the total number of active physicians in the São Paulo State is 97,320, with $39.3 \%$ women ${ }^{3}$.

In the USA, women represent an increasingly large proportion of medical students and the practicing physician work force 4 . In 1960, only about $5 \%$ of medical students in the United States were women; today, the number of women and men in medical school are approximately equal ${ }^{5}$. In the United Kingdom, over $60 \%$ of medical students are women ${ }^{6}$.

Despite the increased entry of women into the medical profession over the past several decades, some have suggested that women may remain substantially underrepresented in senior leadership positions in academic medicine $e^{7,8}$. In a study of faculty members appointed to U. S. medical schools betweeen 1979 and 1981, only 5\% of women, as compared with $23 \%$ of men, had achieved the rank of full professor; the difference was not fully explained by the number of hours worked or the number of articles published ${ }^{9}$. In 2004, women made up only $19 \%$ of associated professor and full professor on the clinical faculties of medical schools'. In $2005,16 \%$ of the editorial board members of 16 prominent biomedical journals, including N Engl J Med, Lancet, JAMA, BMJ, Nature Med, and Science were women ${ }^{8}$. Studies have also documented that women receive lower salaries than men with similar experience and academic rank ${ }^{10,11}$, including among neurologists ${ }^{4}$.

Similarly, although the proportion of women among authors has increased over time, the data suggest that a gender gap in authorship remains, particularly among senior authors. The analysis of authorship of original articles from six prominent medical journals, including $\mathrm{N}$ Engl J Med, JAMA, Ann Intern Med, Ann Surg, Obstet Gynecol, and J Pediatr, showed that the proportion of women serving as fisrt authors increased from $5.9 \%$ to $29.3 \%$ during the period of 1970 and $2004^{1}$. The proportion of women serving as senior authors increased from $3.7 \%$ to $19.3 \%$, and the data suggested that this momentum may be reaching a plateau'. The gender of the 449 corresponding authors of papers submitted to the Journal Nature Neuroscience, from January to March 2005, was female in $92(20.5 \%)^{12}$.

What accounts for the apparent paradox of dramatic growth in the rate of women entering the field of medicine and the achievement of less success in academic medicine by women as compared with men, as least according to the conventional metrics of authorship and promotion? The answer remains unclear, but both institutional barriers to success and sex differences in career and life goals are important ${ }^{5}$. The success in academic medicine has traditionally required working 60 to 70 hours per week, a time commitment that for many is incompatible with the responsabilities associated with raising children'. A questionnaire to examine the life choices made by neurology consultants and trainees showed that both sexes would like to do more part-time work or have a career break. Around $87 \%$ of women were planning to work part-time at some point, primarily for child-care reasons. 
By comparison, $25 \%$ of working male doctors wanted to work part-time or take a career break to pursue sporting ambitions, to travel, or for semi-retirement ${ }^{13}$.

If the proportion of women as physician has only recently reached parity or even light predominance, one cannot expect the principal or senior researcher to approach as equal gender distribution until substantial time has passed.

Our results validate the perception that although women have made substantial strides in the past several decades, a gender gap remains among authors of original articles in prestigious academic medical journals, including the Arquivos de Neuro-Psiquiatria.

\section{REFERENCES}

1. Jagsi R, Guancial EA, Worobey CC, et al. The "gender gap" in authorship of academic medical literature: a 35-year perspective. N Engl J Med 2006;355:281-287.

2. The Brazilian Federal Council of Medicine, 2009. Available at www.portalmedico.org.br/novoportal/index5.asp. Acessed May 21, 2009.
3. Jornal do CREMESP - Conselho Regional de Medicina do Estado de São Paulo 2009;254:12.

4. Weeks WB, Wallace AE. The influence of provider sex on neurologists' annual incomes. Clin Neurol Neurosurg 2007;109:38-44.

5. Hamel MB, Ingelfinger JR, Phimister E, et al. Women in academic medicine: progress and challenges. N Engl J Med 2006;355:310- 312.

6. Butcher J. Women in neurology. Lancet Neurol 2007;6:762.

7. Nonnemaker L. Women physicians in academic medicine: new insights from cohort studies. N Engl J Med 2000;342:399-405.

8. Jagsi R, Tarbell NJ, Henault Chang Y, et al. Representation of women on the editorial board of major medical journals: a 35-year perspective. Arch Intern Med 2008;168:544-548.

9. Tesch BJ, Wood HM, Helwig AL, et al. Promotion of women physician in academic medicine: glass ceiling or sticky floor? JAMA 1995;273: 1022-1025.

10. Ash AS, Carr PL, Goldstein R, Friedman RH. Compensation and advancement of women in academic medicine: is there equity? Ann Intern Med 2004;141:205-212.

11. Carr PL, Friedman RH, Moskowitz MA, et al. Research, academic rank, and compensation of women and men faculty in academic general internal medicine. J Gen Intern Med 1992;7:418-423.

12. Editorial. Women in neuroscience: a number game. Nat Neurosci 2006; 9:853.

13. Carroll CB, Tengah DS, Lawthom C, et al. The feminisation of British neurology: implications for workforce planning. Clin Med 2007;7:339-342. 